\title{
PENENTUAN BOD, ZN, DAN NO3-N DI WADUK SAGULING PADA SETIAP PEMBAGIAN KELAS TAHUN BERDASARKAN DISKRIT MARKOV 3 DAN 5 KELAS (DETERMINATION OF BOD, ZN, AND NO $\mathrm{N}_{3}-\mathrm{N}$ CONCENTRATIONS IN SAGULING RESERVOIR ON EACH YEAR CLASS DIVISION BASED ON DISCRETE MARKOV'S 3 AND 5 CLASS)
}

\author{
Mariana Marselina $^{1 *}$, Arwin Sabar ${ }^{1}$, Indah Rachmatiah Siti Salami', \\ dan Dyah Marganingrum ${ }^{2}$ \\ ${ }^{1}$ Jurusan Teknik Lingkungan, Fakultas Teknik Sipil dan Lingkungan, \\ Jalan Ganesha No. 10, Bandung, 40132. \\ ${ }^{2}$ Lembaga Ilmu Pengetahuan Indonesia, Jalan Cisitu, Bandung, 40132.
}

*Penulis korespondensi. Tel: 081313144101. Email: mariana.marselina@ yahoo.com.

\author{
Diterima: 17 Maret 2017
}

Disetujui: 22 Agustus 2017

\begin{abstract}
Abstrak
Waduk Saguling adalah salah satu dari tiga Waduk Kaskade Citarum yang berlokasi di Kabupaten Bandung. Kondisi kualitas air Waduk Saguling cenderung menunjukkan penurunan, baik disebabkan pencemaran oleh limbah industri, domestik, perikanan, peternakan, dan berbagai aktivitas lainnya di sekitar DAS Citarum Hulu. Tujuan dalam penelitian ini adalah mengimplementasikan model konseptual pencemaran air dimana konsentrasi pencemar bergantung pada kuantitas air yang berkarakteristik acak sehingga penelitian pencemaran air dilakukan menggunakan pendekatan diskrit Markov. Dalam penelitian ini, konsentrasi pencemar merupakan fungsi dari waktu, dalam hal ini waktu ditunjukkan dalam tahun yang akan dibagi atau dikelompokkan berdasarkan Diskrit Markov 3 kelas menjadi kondisi kering, normal, dan basah dan berdasarkan Diskrit Markov 5 kelas menjadi kondisi sangat kering, kering, normal, basah, dan sangat basah. Hasil penelitian menunjukkan bahwa konsentrasi pencemar memiliki nilai yang tinggi pada tahun sangat kering dan nilai yang rendah pada tahun sangat basah. BOD di Pos Nanjung, Pos Muara Ciminyak, dan Pos Intake Turbin secara berturut-turut pada tahun sangat kering adalah 58,62;11,94 dan 12,81 mg/L. Konsentrasi Zn di Pos Nanjung, Pos Muara Ciminyak, dan Pos Intake Turbin secara berturut-turut pada tahun sangat kering adalah 0,11; 0,028; dan 0,030 mg/L. Konsentrasi $\mathrm{NO}_{3}-\mathrm{N}$ di Pos Nanjung, Pos Muara Ciminyak, dan Pos Intake Turbin secara berturut-turut pada tahun sangat kering 3,56 ; 1,91; dan 1,74 mg/L. BOD di Pos Nanjung, Pos Muara Ciminyak, dan Pos Intake Turbin secara berturut-turut pada tahun sangat basah adalah 17,91; 5,86; dan 9,01 mg/L. Konsentrasi Zn di Pos Nanjung, Pos Muara Ciminyak, dan Pos Intake Turbin secara berturut-turut pada tahun sangat basah adalah 0,034; 0,011; dan 0,012 mg/L. Konsentrasi $\mathrm{NO}_{3}-\mathrm{N}$ di Pos Nanjung, Pos Muara Ciminyak, dan Pos Intake Turbin secara berturut-turut pada tahun sangat basah adalah 2,67; 1,26; dan $1,29 \mathrm{mg} / \mathrm{L}$.
\end{abstract}

Kata kunci: diskrit Markov, konsentrasi pencemar, pembagian kelas debit, waduk.

\begin{abstract}
Saguling is one of the three reservoirs of Citarum Cascade located in Bandung Regency, West Java Province. Water quality conditions in Saguling reservoir tend to decrease, either due to pollution by industrial waste, domestic, fisheries, livestock, and also other events around Citarum upstream watershed. The purpose of this research is to implement the conceptual model of water pollution which pollutant concentrations depend on the quantity of water which has random characteristic. Study of water pollution in this research was conducted using Markov discrete approach. In this study, the concentration of pollutants is a function of time where time was indicated of year the the observation years (1999-2013) was divided or grouped by Discrete Markov 3 classes become dry, normal, and wet conditions and also based on Discrete Markov 5 class becomes very dry, dry, normal and wet and very wet conditions. The results showed that the concentrations of pollutants have a high value in a very dry condition and low value at a very wet condition. BOD concentration in Nanjung Station, Muara Ciminyak Station, Turbine Intake Station consecutively in very dry condition was 58.62; 11.94; and 12.81 mg/L. Concentration of Zn in Nanjung Station, Muara Ciminyak Station, and Turbine Intake Station consecutively in very dry condition was 0.11; 0,028; and 0,030 mg/L. $\mathrm{NO}_{3}-\mathrm{N}$ concentration in Nanjung Station, Muara Ciminyak Station, and Turbine Intake Station consecutively in very dry condition was 3.56; 1.91; and $1.74 \mathrm{mg} / \mathrm{L}$. BOD concentration in Nanjung Sation, Muara Ciminyak Station, and Turbine Intake Station consecutively in a very wet condition was 17.91; 5.86; and 9.01 mg/L. Concentration of Zn in Nanjung Station, Muara Ciminyak Station, and Turbine Intake Station consecutively in very wet condition was 0,034; 0,011; and $0.012 \mathrm{mg} / \mathrm{L} . \mathrm{NO}_{3}-\mathrm{N}$ concentration in Nanjung Station, Muara Ciminyak Station, and Turbine Intake Station consecutively in very wet condition was 2.67 ; 1.26 ; and $1.29 \mathrm{mg} / \mathrm{L}$.
\end{abstract}

Keywords: discrete Markov, debit class division, pollutant concentrations, reservoirs. 


\section{PENDAHULUAN}

Waduk Saguling merupakan waduk yang terletak di hulu DAS Citarum membentuk Waduk Kaskade Citarum dimana secara berurutan terdiri Waduk Saguling, Waduk Cirata, dan Waduk Jatiluhur. Hart dkk., (2002) melaporkan bahwa Waduk Saguling telah tercemar berat, khususnya oleh limbah domestik dan efluen industri. Pencemaran materi organik, nutrien, dan logam berat di Waduk Saguling paling besar berasal dari Kota Bandung sehingga Waduk Saguling teridentifikasi sebagai waduk yang sangat tropik (Marganingrum, 2013a). Waduk Saguling telah banyak diteliti sangat mengalami pencemaran sepeti logam berat (Sudarso dkk, 2005) termasuk logam cadmium (Wardhani dkk, 2016), termasuk efeknya pada system biota sekitar (Sudarsono, 2006).

Dalam rangka menghindari terjadinya overload pada badan air termasuk di Waduk Saguling diperlukan kajian mengenai perilaku data kualitas dan kuantitas secara periodik dan teratur pada musim hujan dan pada musim kering (Marganingrum, 2013b). Fan dkk. (2012) melakukan penelitian kualitas air di Pearl River Delta, China pada tahun 1952-2009. Penelitian tersebut menyatakan bahwa terdapat perbedaan dari hasil pengukuran musim hujan dan musim kemarau sepanjang tahun penelitian. Parameter untuk konsentrasi $\mathrm{pH}, \mathrm{BOD}, \mathrm{NH}_{4}, \mathrm{SO}_{4}{ }^{2-}$, dan $\mathrm{Cl}^{-}$pada musim kering lebih tinggi daripada musim hujan.

Sebastia dkk. (2013) melakukan penelitian terhadap kualitas air di cekungan Sungai
Mediterranean dengan membandingkan dua skenario yakni musim hujan dan musim kemarau. Selama musim hujan ditemukan bahwa limpasan limbah pertanian dan aliran sewerage gabungan berpengaruh dominan terhdap pencemaran nutrien, sedangkan pada musim kemarau yang menjadi pencemar utama nutrien adalah limbah domestik yang tidak terolah sepenuhnya. Pada badan air penerima, konsentrasi nutrien yang tinggi disebabkan oleh aliran dari sewerage gabungan selama musim hujan, sedangkan kelimpahan nutrien yang tinggi pada musim kemarau disebabkan pembuangan limbah yang belum terolah sempurna pada turbulensi rendah.

Mengingat nilai strategis Waduk Saguling sebagai pembangkit listrik dan sumber air baku, maka perlu dilakukan upaya pemantauan kualitas air dimana dalam hal ini penentuan konsentrasi pencemar $\mathrm{BOD}, \mathrm{Zn}$, dan $\mathrm{NO}_{3}-\mathrm{N}$ di beberapa lokasi monitoring yaitu Pos Nanjung (inlet), Pos Muara Ciminyak (utara Waduk Saguling), dan Pos Intake Turbin (outlet) yang konsisten dilakukan pada kondisi tahun kelas kering, normal, dan basah.

\section{METODE PENELITIAN}

\section{Waktu dan Lokasi}

Penentuan BOD, $\mathrm{Zn}$, dan $\mathrm{NO}_{3}-\mathrm{N}$ dalam penelitian ini dilakukan di lokasi monitoring Waduk Saguling terpilih yaitu Gambar 1 Pos Nanjung (inlet), Pos Muara Ciminyak (utara Waduk Saguling), dan Pos Intake Turbin (outlet). Data pengukuran $\mathrm{BOD}, \mathrm{Zn}$, dan $\mathrm{NO}_{3}-\mathrm{N}$ yang diolah adalah data dari tahun 1999 hingga 2013.

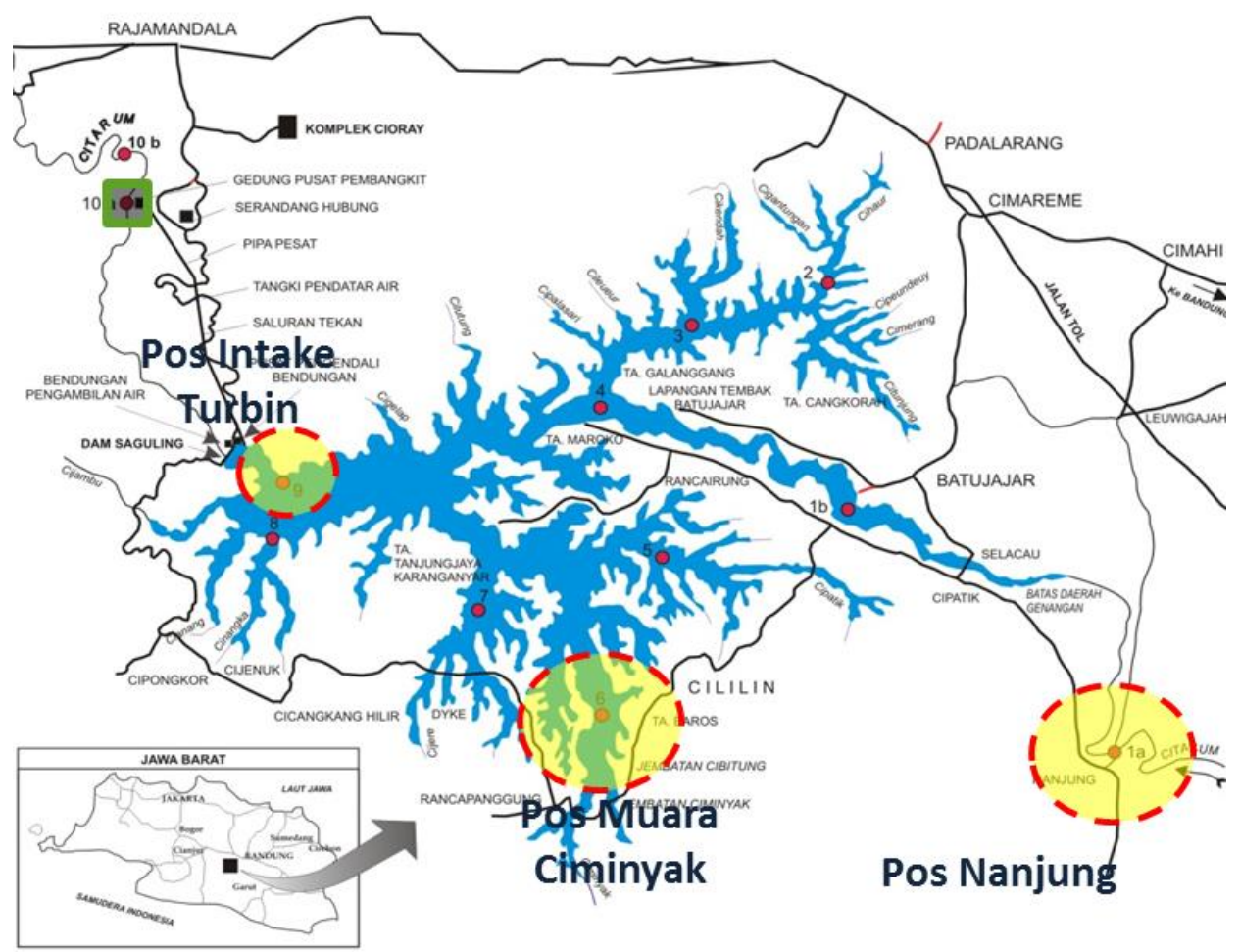

Gambar 1. Lokasi penelitian Waduk Saguling. 


\section{Penentuan Tahun Kering, Normal, Basah dengan Metode Diskrit Markov}

Untuk penentuan tahun kering, normal dan basah menggunakan metode Diskrit Markov tiga kelas, langkah pertama yang dilakukan adalah dengan menyusun data debit tahun 1999-2013 masing-masing pos monitoring terpilih dari besar ke kecil kemudian tahap selanjutnya membagi atau mengelompokkan data debit tersebut kedalam tiga kelas kering, normal dan basah. Di samping itu, pembagian debit juga dilakukan ke dalam kondisi lima kelas yaitu kelas sangat kering, kering, normal, basah, dan sangat basah (Sabar, 2009).

\section{Konsisten Data Debit dan Konsentrasi Parameter Pencemar Terpilih}

Data kualitas tidak terlepas dari data kuantitas mengingat analisis dilakukan berdasarkan stream standard. Selain itu, setiap kontaminan yang dimasukkan ke dalam badan air memiliki variabel berat dan volume (umumnya dengan satuan $\mathrm{mg} / \mathrm{L}$ ), di mana volume terkait dengan komponen kuantitas yang umumnya diukur dalam bentuk debit. Penentuan BOD, $\mathrm{Zn}$, dan $\mathrm{NO}_{3}-\mathrm{N}$ dilakukan pada setiap kelas tahun yang telah terbentuk berdasarkan metode Diskrit Markov baik Diskrit Markov tiga kelas dan Diskrit Markov lima kelas.

\section{HASIL DAN PEMBAHASAN}

\section{Penentuan Konsentrasi Pencemar di Pos Nanjung}

Berdasarkan pembagian kelas tahun pengamatan 1999-2013 berdasarkan Metode Diskrit Markov, diperoleh pembagian kelas tahun kering, normal, dan basah. Pembagian kelas juga dilakukan berdasarkan metode diskrit Markov lima kelas, diperoleh pembagian kelas tahun sangat kering, kering, normal, basah, dan sangat basah.

Berdasarkan Error! Reference source not found. dapat dilihat bahwa BOD pada tahun kering (diskrit Markov 3 kelas) lebih tinggi jika dibandingkan dengan BOD pada tahun basah.
BOD pada tahun kering ditemukan sebesar 47,78 mg/L dan konsentrasi basah ditemukan sebesar 29,16 mg/L. Di samping itu, BOD pada tahun sangat kering (diskrit Markov 5 kelas) lebih tinggi jika dibandingkan dengan BOD pada tahun kering (diskrit Markov 3 kelas). BOD pada tahun sangat basah (diskrit Markov 5 kelas) juga lebih rendah jika dibandingkan dengan BOD pada tahun basah (diskrit Markov 3 kelas). BOD pada tahun sangat kering ditemukan sebesar 58,62 mg/L dan BOD pada tahun sangat basah sebesar 17,91 mg/L.

Data konsentrasi $\mathrm{Zn}$ seperti disajikan pada Tabel 1 menunjukkan bahwa $\mathrm{Zn}$ pada tahun kering (diskrit Markov 3 kelas) lebih tinggi jika dibandingkan dengan konsentrasi $\mathrm{Zn}$ pada tahun basah. Konsentrasi Zn pada tahun kering ditemukan sebesar $0,09 \mathrm{mg} / \mathrm{L}$ dan konsentrasi $\mathrm{Zn}$ pada tahun basah ditemukan sebesar 0,052 $\mathrm{mg} / \mathrm{L}$. Di samping itu, konsentrasi $\mathrm{Zn}$ pada tahun sangat kering (diskrit Markov 5 kelas) lebih tinggi jika dibandingkan dengan konsentrasi $\mathrm{Zn}$ pada tahun kering (diskrit Markov 3 kelas). BOD pada tahun sangat basah (diskrit Markov 5 kelas) juga lebih rendah jika dibandingkan dengan lonsentrasi BOD pada tahun basah (diskrit Markov 3 kelas). BOD pada tahun sangat kering ditemukan sebesar $0,11 \mathrm{mg} / \mathrm{L}$ dan BOD pada tahun sangat basah sebesar 0,034 mg/L.

Berdasarkan Error! Reference source not found. 1 dapat dilihat bahwa konsentrasi $\mathrm{NO}_{3}-\mathrm{N}$ pada tahun kering (diskrit Markov 3 kelas) lebih tinggi jika dibandingkan dengan konsentrasi $\mathrm{NO}_{3}-\mathrm{N}$ pada tahun basah. Konsentrasi $\mathrm{NO}_{3}-\mathrm{N}$ pada tahun kering ditemukan sebesar 3,38 $\mathrm{mg} / \mathrm{L}$ dan konsentrasi $\mathrm{NO}_{3}-\mathrm{N}$ pada tahun basah ditemukan sebesar 2,48 mg/L. Di samping itu, konsentrasi $\mathrm{NO}_{3}-\mathrm{N}$ pada tahun sangat kering (diskrit Markov 5 kelas) lebih tinggi jika dibandingkan dengan konsentrasi $\mathrm{NO}_{3}-\mathrm{N}$ pada tahun kering (diskrit Markov 3 kelas). Konsentrasi $\mathrm{NO}_{3}-\mathrm{N}$ pada tahun sangat kering ditemukan sebesar $3,56 \mathrm{mg} / \mathrm{L}$ dan BOD pada tahun sangat basah sebesar 2,668 mg/L.

Tabel 1. Tingkat BOD, konsentrasi $\mathrm{Zn}$ dan $\mathrm{NO}_{3}-\mathrm{N}$ Waduk Saguling di pos Nanjung pada pembagian debit tahun 3 kelas dan 5 kelas dengan diskrit Markov periode 1999-2013

\begin{tabular}{clccc}
\hline Pembagian debit & \multicolumn{1}{c}{ Kategori } & BOD $(\mathrm{mg} / \mathrm{L})$ & $\mathrm{Zn}(\mathrm{mg} / \mathrm{L})$ & $\mathrm{NO}_{3}-\mathrm{N}(\mathrm{mg} / \mathrm{L})$ \\
\hline \multirow{2}{*}{ Kelas diskrit Markow } & Tahun kering & 47,78 & 0,09 & 3,38 \\
& Tahun normal & 40,41 & 0,06 & 2,94 \\
& Tahun basah & 29,16 & 0,05 & 2,48 \\
\hline \multirow{2}{*}{5 Kelas diskrit Markow } & Tahun sangat kering & 58,62 & 0,11 & 3,56 \\
& Tahun kering & 42,44 & 0,08 & 3,15 \\
& Tahun normal & 42,87 & 0,11 & 3,08 \\
& Tahun basah & 41,47 & 0,04 & 2,98 \\
& Tahun sangat basah & 17,91 & 0,03 & 2,67 \\
\hline
\end{tabular}


Tabel 2 Tingkat BOD, konsentrasi $\mathrm{Zn}$ dan $\mathrm{NO}_{3}-\mathrm{N}$ Waduk Saguling di pos Muara Ciminyak pada pembagian debit tahun 3 kelas dan 5 kelas dengan diskrit Markov periode 1999-2013

\begin{tabular}{clccc}
\hline Pembagian debit & \multicolumn{1}{c}{ Kategori } & BOD $(\mathrm{mg} / \mathrm{L})$ & $\mathrm{Zn}(\mathrm{mg} / \mathrm{L})$ & $\mathrm{NO}_{3}-\mathrm{N}(\mathrm{mg} / \mathrm{L})$ \\
\hline \multirow{2}{*}{ Kelas diskrit Markow } & Tahun kering & 10,27 & 0,02 & 1,82 \\
& Tahun normal & 10,12 & 0,02 & 1,47 \\
& Tahun basah & 9,23 & 0,02 & 1,28 \\
\hline \multirow{2}{*}{ 5 Kelas diskrit Markow } & Tahun sangat kering & 11,94 & 0,03 & 1,91 \\
& Tahun kering & 10,88 & 0,02 & 1,89 \\
& Tahun normal & 8,67 & 0,01 & 1,85 \\
& Tahun basah & 8,20 & 0,01 & 1,85 \\
& Tahun sangat basah & 5,86 & 0,01 & 1,26 \\
\hline
\end{tabular}

Tabel 3 Tingkat BOD, konsentrasi $\mathrm{Zn}$ dan $\mathrm{NO}_{3}-\mathrm{N}$ Waduk Saguling di pos intake turbin pada pembagian debit tahun 3 kelas dan 5 kelas dengan diskrit Markov periode 1999-2013

\begin{tabular}{clccc}
\hline Pembagian debit & \multicolumn{1}{c}{ Kategori } & BOD $(\mathrm{mg} / \mathrm{L})$ & $\mathrm{Zn}(\mathrm{mg} / \mathrm{L})$ & $\mathrm{NO}_{3}-\mathrm{N}(\mathrm{mg} / \mathrm{L})$ \\
\hline \multirow{2}{*}{ Kelas diskrit Markow } & Tahun kering & 12,64 & 0,02 & 1,63 \\
& Tahun normal & 12,36 & 0,02 & 1,54 \\
& Tahun basah & 11,02 & 0,02 & 1,31 \\
\hline 5 Kelas diskrit Markow & Tahun sangat kering & 12,81 & 0,03 & 1,74 \\
& Tahun kering & 12,74 & 0,02 & 1,68 \\
& Tahun normal & 12,19 & 0,02 & 1,42 \\
& Tahun basah & 10,06 & 0,02 & 1,30 \\
& Tahun sangat basah & 9,01 & 0,01 & 1,29 \\
\hline
\end{tabular}

\section{Penentuan Konsentrasi Pencemar di Pos Muara Ciminyak}

Dari Error! Reference source not found.2 dapat dilihat bahwa BOD pada tahun kering (diskrit Markov 3 kelas) lebih tinggi jika dibandingkan dengan BOD pada tahun basah. BOD pada tahun kering ditemukan sebesar 10,27 $\mathrm{mg} / \mathrm{L}$ dan konsentrasi basah ditemukan sebesar 9,23 mg/L. Di samping itu, BOD pada tahun sangat kering (diskrit Markov 5 kelas) lebih tinggi jika dibandingkan dengan BOD pada tahun kering (diskrit Markov 3 kelas). BOD pada tahun sangat basah (diskrit Markov 5 kelas) juga lebih rendah jika dibandingkan dengan lonsentrasi BOD pada tahun basah (diskrit Markov 3 kelas). BOD pada tahun sangat kering ditemukan sebesar $11,94 \mathrm{mg} / \mathrm{L}$ dan BOD pada tahun sangat basah sebesar $5,86 \mathrm{mg} / \mathrm{L}$.

Berdasarkan tabel 2 dapat dilihat bahwa konsentrasi $\mathrm{Zn}$ pada tahun kering (diskrit Markov 3 kelas) lebih tinggi jika dibandingkan dengan konsentrasi Zn pada tahun basah. Konsentrasi Zn pada tahun kering ditemukan sebesar 0,019 mg/L dan konsentrasi $\mathrm{Zn}$ pada tahun basah ditemukan sebesar 0,016 mg/L. Di samping itu, konsentrasi Zn pada tahun sangat kering (diskrit Markov 5 kelas) lebih tinggi jika dibandingkan dengan konsentrasi $\mathrm{Zn}$ pada tahun kering (diskrit Markov 3 kelas).

Untuk konsentrasi $\mathrm{NO}_{3}-\mathrm{N}$ pada tahun kering (diskrit Markov 3 kelas) diketahui lebih tinggi jika dibandingkan dengan konsentrasi $\mathrm{NO}_{3}-\mathrm{N}$ pada tahun basah. Konsentrasi $\mathrm{NO}_{3}-\mathrm{N}$ pada tahun kering ditemukan sebesar $1,82 \mathrm{mg} / \mathrm{L}$ dan konsentrasi $\mathrm{NO}_{3-}$ $\mathrm{N}$ pada tahun basah ditemukan sebesar $1,28 \mathrm{mg} / \mathrm{L}$. Di samping itu, konsentrasi $\mathrm{NO}_{3}-\mathrm{N}$ pada tahun sangat kering (diskrit Markov 5 kelas) lebih tinggi jika dibandingkan dengan konsentrasi $\mathrm{NO}_{3}-\mathrm{N}$ pada tahun kering (diskrit Markov 3 kelas). Konsentrasi $\mathrm{NO}_{3}-\mathrm{N}$ pada tahun sangat kering ditemukan sebesar $1,91 \mathrm{mg} / \mathrm{L}$ dan BOD pada tahun sangat basah sebesar $1,26 \mathrm{mg} / \mathrm{L}$.

\section{Penentuan Konsentrasi Pencemar BOD di Pos Intake Turbin}

Untuk pos intake turbin data merujuk pada Error! Reference source not found.3. BOD pada tahun kering (diskrit Markov 3 kelas) lebih tinggi jika dibandingkan dengan BOD pada tahun basah. BOD pada tahun kering ditemukan sebesar 12,64 $\mathrm{mg} / \mathrm{L}$ dan konsentrasi basah ditemukan sebesar 11,02 mg/L. Di samping itu, BOD pada tahun sangat kering (diskrit Markov 5 kelas) lebih tinggi jika dibandingkan dengan BOD pada tahun kering (diskrit Markov 3 kelas). BOD pada tahun sangat basah (diskrit Markov 5 kelas) juga lebih rendah jika dibandingkan dengan lonsentrasi BOD pada tahun basah (diskrit Markov 3 kelas). BOD pada tahun sangat kering ditemukan sebesar 12,81 mg/L dan BOD pada tahun sangat basah sebesar 9,01 $\mathrm{mg} / \mathrm{L}$.

Konsentrasi $\mathrm{Zn}$ pada tahun kering (diskrit Markov 3 kelas) lebih tinggi jika dibandingkan dengan konsentrasi $\mathrm{Zn}$ pada tahun basah. Konsentrasi $\mathrm{Zn}$ pada tahun kering ditemukan sebesar $0,019 \mathrm{mg} / \mathrm{L}$ dan konsentrasi $\mathrm{Zn}$ pada tahun basah ditemukan sebesar 0,016 mg/L. Di samping itu, konsentrasi Zn pada tahun sangat kering (diskrit Markov 5 kelas) lebih tinggi jika dibandingkan 
dengan konsentrasi $\mathrm{Zn}$ pada tahun kering (diskrit Markov 3 kelas).

Berdasarkan Error! Reference source not found.3 dapat dilihat bahwa konsentrasi $\mathrm{NO}_{3}-\mathrm{N}$ pada tahun kering (diskrit Markov 3 kelas) lebih tinggi jika dibandingkan dengan konsentrasi $\mathrm{NO}_{3}-\mathrm{N}$ pada tahun basah. Konsentrasi $\mathrm{NO}_{3}-\mathrm{N}$ pada tahun kering ditemukan sebesar 1,63 $\mathrm{mg} / \mathrm{L}$ dan konsentrasi $\mathrm{NO}_{3}-\mathrm{N}$ pada tahun basah ditemukan sebesar 1,31 mg/L. Di samping itu, konsentrasi $\mathrm{NO}_{3}-\mathrm{N}$ pada tahun sangat kering (diskrit Markov 5 kelas) lebih tinggi jika dibandingkan dengan konsentrasi $\mathrm{NO}_{3}-\mathrm{N}$ pada tahun kering (diskrit Markov 3 kelas). Konsentrasi $\mathrm{NO}_{3}-\mathrm{N}$ pada tahun sangat kering ditemukan sebesar $1,74 \mathrm{mg} / \mathrm{L}$ dan BOD pada tahun sangat basah sebesar $1,29 \mathrm{mg} / \mathrm{L}$.

Perbandingan $\mathrm{BOD}, \mathrm{Zn}$, dan $\mathrm{NO}_{3}-\mathrm{N}$ pada $\mathrm{Pos}$ Nanjung, Muara Ciminyak, dan Intake Turbin

Pada Gambar 2 dapat dilihat bahwa BOD tertinggi terdapat di Pos Nanjung, kemudian Pos Intake, dan Pos Muara Ciminyak. Hal ini diakibatkan aktivitas DAS Nanjung yang lebih banyak menghasilkan pencemar BOD yakni kegiatan domestik atau rumah tinggi. DAS lokal Muara Ciminyak lebih banyak didominasi oleh kegiatan Keramba Jaring Apung sehingga BOD terukur di Pos Muara Ciminyak lebih kecil konsentrasinya.

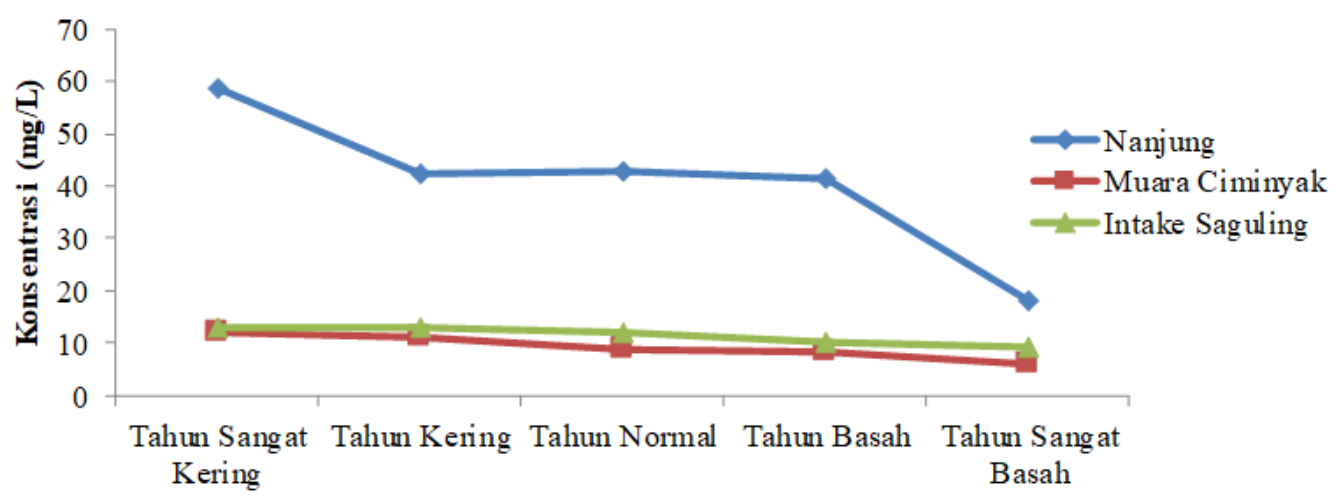

Gambar 2. BOD di Pos Nanjung, Muara Ciminyak, dan Intake Turbin

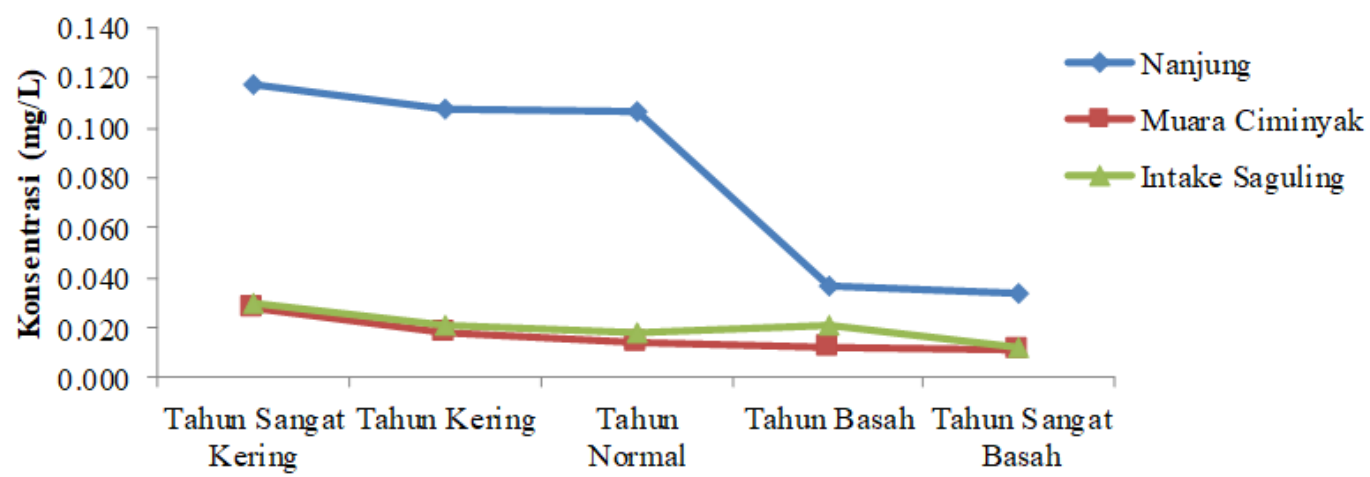

Gambar 3. Konsentrasi Zn di Pos Nanjung, Muara Ciminyak, dan Intake Saguling

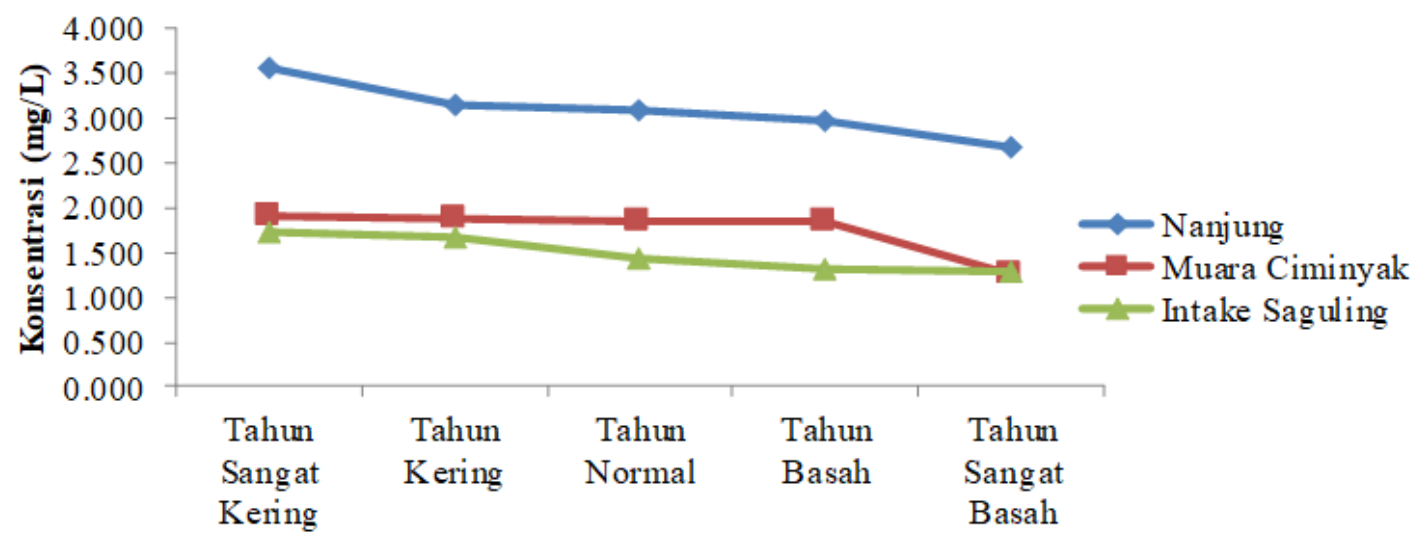

Gambar 4. Konsentrasi $\mathrm{NO}_{3}-\mathrm{N}$ di Pos Nanjung, Muara Ciminyak, dan Intake Saguling. 
Gambar 3 menunjukkan konsentrasi Zn juga tetap ditemukan paling tinggi di Pos Nanjung, kemudian Pos Intake dan Muara Ciminyak. Hal ini disebabkan banyaknya aktivitas industri yang berada di sekitar DAS Nanjung. Zn termasuk dalam kelompok logam berat yang dihasilkan dari efluen kegiatan industri.

Konsentrasi $\mathrm{NO}_{3}-\mathrm{N}$ seperti ditunjukkan pada Gambar 4 terlihat lebih tinggi ditemukan di Pos Nanjung, kemudian Pos Muara Ciminyak, dan Pos Intake Saguling. Aktivitas yang terjadi di Pos Nanjung seperti pertanian dan peternakan merupakan salah satu penyebab tingginya pencemar $\mathrm{NO}_{3}-\mathrm{N}$ di Pos Nanjung. Dapat dilihat konsentrasi $\mathrm{NO}_{3}-\mathrm{N}$ di Pos Muara Ciminyak lebih tinggi daripada di Pos Intake, hal ini dapat diakibatkan oleh kegiatan atau aktivitas Keramba Jaring Apung yang mendominasi DAS lokal Muara Ciminyak.

\section{KESIMPULAN}

Konsentrasi pencemar merupakan fungsi dari waktu dimana dalam penelitian ini waktu dikondisikan dengan metode diskrit Markov 3 kelas dan diskrit Markov 5 kelas. Penelitian pencemaran air Waduk Saguling dengan pendekatan diskrit menunjukkan konsentrasi pencemar (BOD, Zn, $\mathrm{NO}_{3}-\mathrm{N}$ ) lebih tinggi pada kondisi tahun kering dan sangat kering dan lebih rendah pada kondisi tahun hujan dan sangat hujan. Hal ini ditemukan baik di Pos Nanjung, Pos Muara Ciminyak, dan Pos Intake Turbin.

BOD tertinggi terdapat di Pos Nanjung, kemudian Pos Intake, dan Pos Muara Ciminyak. Hal ini diakibatkan aktivitas DAS Nanjung yang lebih banyak menghasilkan pencemar BOD yakni kegiatan domestik atau rumah tinggal. DAS lokal Muara Ciminyak lebih banyak didominasi oleh kegiatan Keramba Jaring Apung sehingga BOD terukur di Pos Muara Ciminyak lebih kecil konsentrasinya. Konsentrasi $\mathrm{Zn}$ juga tetap ditemukan paling tinggi di Pos Nanjung, kemudian Pos Intake dan Muara Ciminyak. Hal ini disebabkan banyaknya aktivitas industri yang berada di sekitar DAS Nanjung. Konsentrasi $\mathrm{NO}_{3-}$ $\mathrm{N}$ lebih tinggi ditemukan di Pos Nanjung, kemudian Pos Muara Ciminyak, dan Pos Intake Saguling. Aktivitas yang terjadi di Pos Nanjung seperti pertanian dan peternakan merupakan salah satu penyebab tingginya pencemar $\mathrm{NO}_{3}-\mathrm{N}$ di Pos
Nanjung. Dapat dilihat konsentrasi $\mathrm{NO}_{3}-\mathrm{N}$ di Pos Muara Ciminyak lebih tinggi daripada di Pos Intake, hal ini dapat diakibatkan oleh kegiatan atau aktivitas Keramba Jaring Apung yang mendominasi DAS lokal Muara Ciminyak.

\section{DAFTAR PUSTAKA}

Fan, X., Cui, B., Zhang, K., Zhang, Z., dan Shao, H.,. 2012. Water Quality Management Based on Division of Dry and Wet Seasons in Pearl River Delta, China. Clean - Soil, Air, Water, 40:381-393

Hart, B., van Dok, W., dan Djuangsih, N., 2002. Nutrient Budget for Saguling Reservoir, West Java, Indonesia. Water Research, 36:21522160.

Marganingrum, D., 2013a. Manajemen Sumberdaya Air Terpadu "Waduk Saguling" Dalam Rangka Pengembangan SPAM Regional KSN Cekungan Bandung. Disertasi Program Penelitian Teknik Lingkungan ITB.

Marganingrum, D., 2013b. Penilaian Mutu Air Sungai dengan Pendekatan Perbedaan Hasil dari Dua Metode Indeks. Buletin Geologi Tata Lingkungan, 24:105-114

Sabar, A., 2009. Perubahan Iklim,Konversi Lahan dan Ancaman Banjir dan Kekeringan Di Kawasan Terbangun. Pidato Ilmiah Guru Besar, ITB Bandung.

Sebastia, M.T., Rodilla, M., Falco, S., dan Sanchis J.A., 2013. Analysis of The Effects of Wet and Drt Seasons on A Mediterranean River Basin: Consequences for Coastal Waters and Its Quality Management. Ocean \& Coastal Management, 78, 45-55.

Sudarso, Y., Yoga, G.P., dan Suryono, T., 2005. Kontaminasi Logam Berat Di Sedimen: Studi Kasus Pada Waduk Saguling Jawa Barat. J. Manusia \& Lingkungan, 12(1):28-42.

Sudarsono, Y., 2006. Pengaruh Kontaminasi Logam Berat Terhadap Kecacatan Larva (Dicrotendipes Simpsoni) (Diptera: Chironomidae): Studi Kasus Di Waduk Saguling Jawa Barat. J. Manusia \& Lingkungan, 13(3):26-40.

Wardhani, E., Roosmini, D., dan Notodarmojo, S., 2016. Pencemaran Kadmium Di Sedimen Waduk Saguling Provinsi Jawa Barat. $J$. Manusia \& Lingkungan, 23(3):285-294. 